\title{
Kinetic modeling of inactivation of \\ foodborne bacterial pathogens in serrano \\ artisanal cheese during ripening
}

\section{Modelagem cinética de inativação de bactérias patogênicas em \\ queijo artesanal serrano durante a maturação}

\author{
Ângelo Nardi Pretto1, Carolina Reck², Álvaro Menin², Voltaire Sant'Anna ${ }^{\text {** (D) }}$ \\ ${ }^{1}$ Universidade Estadual do Rio Grande do Sul (UERGS), Área da Vida e Meio Ambiente, Encantado/RS - Brasil \\ ${ }^{2}$ Vertà Instituto de Pesquisa e Diagnóstico Veterinário, Curitibanos/SC - Brasil
}

*Corresponding Author: Voltaire Sant'Anna, Universidade Estadual do Rio Grande do Sul (UERGS), Campus São

Francisco de Paula, Rua Assis Brasil, 842, CEP: 95400-000, Encantado/RS - Brasil, e-mail: voltaire-

santanna@uergs.edu.br

Cite as: Pretto, A. N., Reck, C., Menin, A., \& Sant'Anna, V. (2021). Kinetic modeling of inactivation of foodborne bacterial pathogens in serrano artisanal cheese during ripening. Brazilian Journal of Food Technology, 24,

e2019322. https://doi.org/10.1590/1981-6723.32219

\begin{abstract}
Serrano artisanal cheese is a traditional raw milk dairy product from southern Brazil. For safe consumption of raw milk products, ripening is a critical period for reducing populations of pathogenic and spoilage microorganism and, then, the knowledge on inactivation kinetics of microorganisms is necessary to guarantee food safety and quality. In the present work, inactivation kinetics of foodborne bacterial pathogens required by Brazilian regulations in serrano artisanal cheeses were statistically evaluated during ripening. The Salmonella spp., Listeria monocytogenes, coagulase-positive strain of Staphylococcus aureus and fecal coliforms were analyzed for up to 60 days. Experimental data were fitted using first-order model, Weibull and log-linear + shoulder models. Results showed no presence of Salmonella spp. and L. monogyatogenes in the cheeses through the studied period. The first-order and Weibull models presented good performance to represent coagulase-positive strain of $S$. aureus and fecal coliforms during ripening, although Weibull distribution showed better outcomes to experimental data. Log-linear+shoulder equation was discarded to describe the reduction of microorganism counts for physical criteria. Kinetics showed an initial resistance of fecal coliforms to be inactivated, unlike to coagulase-positive strain of $S$. aureus population. Modeling analysis allowed estimating serrano artisanal cheese ripening period to be longer than 33 days for achieving a safe product according to the Brazilian Regulatory Standards.
\end{abstract}

Keywords: Ripening; Raw milk cheese; Artisanal cheese; Inactivation; Kinetic modeling; Weibull model.

\section{Resumo}

O queijo artesanal serrano é um queijo tradicional de leite cru no sul do Brasil. Para o consumo seguro de produtos lácteos não pasteurizados, a maturação é um período crítico para reduzir populações de microrganismos patogênicos e deteriorantes, sendo, portanto, necessário o conhecimento da cinética de inativação de microrganismos para garantir a segurança e a qualidade dos alimentos. No presente trabalho, a cinética de inativação de patógenos de origem alimentar exigida pela regulamentação brasileira em queijos artesanais serrano 
foi avaliada estatisticamente durante a maturação. Salmonella spp., Listeria monocytogenes, Staphylococcus aureus coagulase positivo e coliformes fecais foram analisados por até 60 dias. Os dados experimentais foram ajustados aos modelos de primeira ordem de inativação, Weibull e log-linear + ombro. Os resultados mostraram que os queijos são seguros para a presença de Salmonella spp. e L. monogyatogenes ao longo do período estudado. Os modelos de primeira ordem e Weibull apresentaram bom desempenho para representar $S$. aureus coagulase positiva e coliformes fecais durante a maturação, embora a distribuição de Weibull tenha se mostrado melhor para descrever os dados experimentais. A equação log-linear + ombro foi descartada para descrever a redução na contagem de microrganismos por critérios físicos. A cinética mostrou resistência inicial dos coliformes fecais a serem inativados, diferentemente da população de $S$. aureus coagulase positiva. A análise de modelagem permitiu estimar o período de maturação do queijo serrano em mais de 33 dias para a obtenção de um produto seguro, de acordo com as normas brasileiras.

Palavras-chave: Maturação; Queijo de leite cru; Queijo artesanal; Inativação; Modelagem cinética; Modelo de Weibull.

\section{Introduction}

Serrano artisanal cheese is a raw milk artisanal product, which is produced in Campos de Cima da Serra from southern Brazil for more than 200 years, which production process has been slightly changed since then. An important characteristic of this type of cheese is associated with its cow milk production, i.e., the animals are fed in native pastures, especially in spring and summer seasons when the grass is richer in nutrients. In general, with respect to the serrano artisanal cheese, the commercial use is carried out from 15 to 30 days of ripening, when the product is characterized by a semi-hard cheese and presents intense flavor and yellowish color (Cruz \& Menasche, 2014).

The food safety of unpasteurized milk cheeses has been widely discussed in Brazil, especially the artisanal ones, since they are more susceptible to be contaminated by foodborne bacterial and fungal pathogens such as Listeria monocytogenes, Escherichia coli, Staphylococcus aureus, among others (Carmo et al., 2002; Haeghebaert et al., 2003; Cremonesi et al., 2007; Brooks et al., 2012; Fava et al., 2012; Ombarak et al., 2016). However, the safety regarding dairy products is not only related to the raw milk quality. Yoon et al. (2016) could associate the quality of raw milk cheese to Good Manufacturing Practices (GMP), as well as ripening working as an important tool to control undesirable microorganisms (Pretto \& Sant'Anna, 2017).

Cheese ripening causes biochemical modifications such as proteolysis and lipolysis, due to bacteria population present in the product, mainly Lactic Acid Bacteria (LAB) (Leclercq-Perlat et al., 2015). In addition to developing a wide variety of flavors and texture, these bacteria (LAB) also produce substances with antimicrobial properties, such as organic acids and bacteriocins, which decisively assist in controlling the growth of spoilage and pathogenic microorganisms in cheeses. Additionally, during maturation process, cheeses present strong reductions in moisture and $\mathrm{pH}$, and an increase in the concentration of sodium chloride, leading to control the growth of undesirable bacteria and contributing to the development of beneficial microorganisms responsible for flavor and texture in cheeses (Leclercq-Perlat et al., 2015; Callon et al., 2016).

Brazilian Regulatory Standards require unpasteurized milk cheeses to be ripened for 60 days at temperatures above $5{ }^{\circ} \mathrm{C}$ (Brasil, 2017). This period of maturation can be reduced if scientific studies may prove that the process is associated with safe production (Brasil, 2017). Cruz \& Menasche (2014) observed that the commercial use of serrano artisanal cheese is carried out in the region of Campos de Cima da Serra (Brazil) from 15 to 30 days of ripening. In this sense, the knowledge of bacterial inactivation kinetics are important tools to establish correctly and accurately maturation period of serrano artisanal cheeses, since mathematical models consist of equations that provide an output based on an input data set and represent a concise way to express physical behavior in mathematical terms. Thus, the objective of the present work 
aimed to establish inactivation kinetics models of pathogenic bacteria according to the Brazilian Regulatory Standards and also verify the ideal ripening time for serrano artisanal cheese.

\section{Materials and methods}

\subsection{Cheese and ripening}

Serrano artisanal cheeses were obtained from inspected family agro-industries that were legalized in the city of São Francisco de Paula (RS, Brazil) from September 2016 to March 2017 and presented average mass of $500 \mathrm{~g}$. Dairy products were produced from raw milk and followed traditional procedure of serrano artisanal cheese production. Milk was immediately conducted to cheese manufacturing with average temperature of $\sim 40{ }^{\circ} \mathrm{C}$, without starter cultures to control the ripening process. Salting was carried out using dry salt that was added onto shaped cheese surface. The mode of production of serrano artisanal cheese is based on the producers' know-how, and, therefore, there are any product patterns neither for the milk nor for the final product (Cruz \& Schneider, 2010; Cruz \& Menasche, 2014).

Ripening occurred in the agro-industry maturation chamber for up to 60 days at temperature of $\sim 10{ }^{\circ} \mathrm{C}$. It is important to point out that the present study (cheese production and ripening) was performed in the family agro-industry of cheese production and not in the laboratory, in which the results make to look like a "real world" in relation to those performed in laboratory conditions.

\subsection{Microbiological analyzes}

Brazilian Regulatory Standards require analyzes of fecal coliforms, such as S. aureus, Salmonella spp. and L. monocytogenes for commercialization of medium moisture cheeses (Brasil, 2001). Microbiological analyzes were performed based on official Brazilian methodology (Brasil, 2003).

For fecal coliform population count, $25 \mathrm{~g}$ of food were homogenized with $225 \mathrm{~mL}$ of $0.1 \%(\mathrm{w} / \mathrm{v})$ peptone water and further decimal dilutions, which were added onto Red Violet Bile Agar at $36^{\circ} \mathrm{C}$ for $24 \mathrm{~h}$. Typical Colony Forming Units (CFU) were selected and transferred to Duhram tubes with EC broth and incubated at $45{ }^{\circ} \mathrm{C}$ for $48 \mathrm{~h}$ when the presence of gas formation was verified. Results were expressed as CFU of fecal coliforms per gram of cheese.

For analyzing coagulase-positive strain of $S$. aureus, aliquots of serial dilutions of the dairy product in $0.1 \%(\mathrm{w} / \mathrm{v})$ peptone water were added onto Baird-Parker agar and incubated at $36{ }^{\circ} \mathrm{C}$ for $48 \mathrm{~h}$ when typical CFU were verified. For coagulase-positive analyzes, typical CFU were transferred to Brain Heart Infusion (BHI) broth for $24 \mathrm{~h}$ at $36^{\circ} \mathrm{C}$ when aliquots were added to rabbit plasma and coagulation was observed. Results were expressed as CFU of coagulase-positive strain of $S$. aureus per gram of cheese.

For Samonella spp. analyzes, $25 \mathrm{~g}$ of cheese were diluted into $225 \mathrm{~mL}$ of non-selective buffered peptone distilled water (ADPT) and incubated at $35^{\circ} \mathrm{C}$ for 24 hours, when the culture was transferred to tubes with Rappaport broth and kept at $41{ }^{\circ} \mathrm{C}$ for 24 hours. Then, selective-differential plating was performed in Salmonella-Shigella Agar and Bright Green Agar and plates and kept at $35^{\circ} \mathrm{C}$ for 24 hours, when the presence of typical CFU were verified. Results were expressed as presence or absence of Salmonella in $25 \mathrm{~g}$ of product (Brasil, 2001, 2003).

L. monocytogenes was verified by dilution of $25 \mathrm{~g}$ of cheese in Listeria selective enrichment broth for $24 \mathrm{~h}$ at $30{ }^{\circ} \mathrm{C}$, when aliquots were transferred to Fraser broth and kept for $48 \mathrm{~h}$ at $36^{\circ} \mathrm{C}$. Colonys from the Fraser system were transferred to Oxford agar, Palcam agar and Tryptose Nalidixic Acid agar and incubated at $36{ }^{\circ} \mathrm{C}$ for $72 \mathrm{~h}$, when typical CFU were observed. Results were expressed as presence or absence of L.monocytogenes in $25 \mathrm{~g}$ of product (Brasil, 2001, 2003). 


\subsection{Kinetic models}

Microbial inactivation has been described as following, according to first-order model (Grosulescu et al., 2011; Benlloch-Tinoco et al., 2014; Gayán et al., 2016) as described in Equation 1.

$\frac{N}{N o}=\exp (-k t)$

Due to the complexity of reaction that may happen during bacterial inactivation, Weibull distribution (Equation 2) has been also proposed for modeling this kinetic behavior.

$$
\frac{N}{N o}=\exp \left(-b t^{n}\right)
$$

In Equations 1 and 2, $N$ is related to the bacteria population in time $t, N_{0}$ is the initial bacteria population in the cheese, $k$ and $b$ are associated to the inactivation constant rate and $n$ determines the shape of the distribution curve in Weibull model.

The "log-linear + shoulder" model is presented in Equation 3 and takes into account a shoulder phase before inactivation occurs (Geeraerd et al., 2000). It has been tested to represent L. monocytogenes inactivation on raw sheep milk cheese (Valero et al., 2014).

$\frac{N}{N_{0}}=\cdot \exp \left(-k_{\max } t\right) \cdot \frac{\exp \left(k_{\max }\right) S l}{1+\left[\exp \left(k_{\max } \cdot S l\right)-l\right] \cdot \exp \left(-k_{\max } t\right)}$

where $k_{\max }$ is the maximum inactivation rate, and $S l$ is the length of the lag phase.

\subsection{Statistical treatment of models}

$N / N_{0}$ with respect incubation times for the different bacteria analyzed were fitted to Equations 1-3, using Gauss-Newton non-linear regression from Statistica 7.0 (StatSoft Inc., Tulsa, OK). Coefficient of correlation $\left(r^{2}\right)$, chi-square $\left(\chi^{2}\right)$ and Standard Error of Means (SEM) were the statistical criteria for comparison of kinetic models.

Chi-square was calculated by Equation 4:

$\chi^{2}=\frac{\sum\left(a_{\text {mensured }}-a_{\text {predicted }}\right)^{2}}{(m-p)}$

SEM estimation is given by Equation 5:

$S E M=\frac{\sum\left(a_{\text {measured }}-a_{\text {predicted }}\right)^{2}}{\sqrt{m}}$

where $m$ is the number of observations and $p$ the number of parameters.

The model with the lowest $\chi^{2}$ and SEM, and higher $r^{2}$ for the $N / N_{0}$ is the best choice from the point of view of statistical performance of a method. Estimation of negative kinetic parameter is a physical criterion for rejecting a model (Sant'Anna et al., 2010).

\section{Results and discussion}

Inactivation data of foodborne bacteria during ripening of serrano artisanal cheese were evaluated. Results showed that the dairy products did not present positive results for Salmonella spp. and L. monocytogenes through the maturation period. Then, data of fecal coliforms and coagulase-positive strain of $S$. aureus population were fitted to first-order model, log-linear + shoulder model and Weibull models, and the statistical performance of the mathematical equations are showed in Table 1. 
Table 1. Statistical performance of kinetic models to describe inactivation of fecal coliforms and coagulase-positive strain of $S$. aureus in serrano artisanal cheese during ripening.

\begin{tabular}{|c|c|c|c|c|c|c|}
\hline & \multicolumn{3}{|c|}{ First-order model } & \multicolumn{3}{|c|}{ Weibull model } \\
\hline & $r^{2}$ & $\chi^{2}$ & SEM & $r^{2}$ & $\chi^{2}$ & SEM \\
\hline Fecal coliforms & 0.875 & 0.0132 & 0.0270 & 0.910 & 0.0122 & 0.0200 \\
\hline $\begin{array}{l}\text { Coagulase-positive strain of } \\
\text { S. aureus }\end{array}$ & 0.985 & 0.0033 & 0.0066 & 0.959 & 0.0040 & 0.0066 \\
\hline
\end{tabular}

*"log-linear + shoulder" was rejected due to estimation of negative constants for fecal coliforms and coagulase-positive strain of S. aureus.

Fitting the experimental data to "log-linear + shoulder" equation by Gauss-Newton non-linear regression could estimate negative constants for fecal coliforms and $S$. aureus, indicating rejection of the model. The $r^{2}$-values for inactivation of fecal coliforms and coagulase-positive strain of $S$. aureus fitted to first-order model were 0.875 and 0.985 , respectively. However, when they were fitted to Weibull distribution, the values were 0.910 and 0.959 . The $\chi^{2}$-values of fecal coliforms and $S$. aureus fitted to first-order model were 0.0132 and 0.0033 , respectively. When they were fitted to Weibull distribution, the values were 0.0122 and 0.0040 , respectively. The SEM values of fecal coliforms and coagulase strain of $S$. aureus fitted to first-order model were 0.0270 and 0.0066 , respectively; though when they were fitted to Weibull distribution, the values were 0.0200 and 0.0066 , respectively. Results showed that $\chi^{2}$-and SEM-values for both models could be performed similarly. However, Weibull equation fitted better than first-order model for $r^{2}$-values.

To minimize errors and optimize product final quality, choosing the best mathematical equation to represent processing curves is essential. When the purpose is predictive modeling, it is recommendable to choose the model in which the fewest parameters are estimated since it is the easiest equation to use. Moreover, simpler equations are stable, because the parameters are the least correlated with it. Furthermore, the model with the fewest parameters has the largest number of degrees of freedom, which can be important when the number of measurements is small (Schokker \& van Boekel, 1997). In this sense, Weibull model seems to be the best equation to represent fecal coliforms and coagulase-positive strain of S. aureus in serrano artisanal cheese during ripening. Graphical representation of $N / N_{0}$ through maturation time is presented in Figure 1. Experimental data showed best fit line to tendency curves, which were estimated by Equations 6 and 7, representing inactivation of fecal coliforms and coagulase-positive strain of $S$. aureus, respectively.

$\frac{N}{N o}=\exp \left(-0.0066 t^{1.387}\right)$

$\frac{N}{N o}=\exp \left(-0.0294 t^{0.964}\right)$

A Weibull distribution with $n>1$ indicated that the semilogarithmic inactivation curve had a downward concavity, i.e., a "shoulder", suggesting that bacterial population presented an initial resistance to inactivation. This fact can be observed in Figure 1, which is reinforced by $n$-value equal to 1.387 for fecal coliforms. The $n$-values less than 1 indicate the 'tailing' phenomena, since tendency curve had an upward concavity, suggesting cells became increasingly susceptible and consequently was difficult for them to survive (van Boekel, 2002). The first-order approach $(n=1)$ assumes that there is no biological variation and microorganism population that may confer the same probability of death rate (van Boekel, 2002; Corradini \& Peleg, 2004). Results from the present work suggested that Weibull model was better to represent inactivation of the bacteria than first-order model and, thus, there is variation sensitivity among cells of a population of the same microorganisms in the dairy product. Valero et al. (2014) observed that L. monocytogenes population reduction in raw sheep milk cheese presented an initial resistance to decay and, thus, the plots showed a downward concavity. In this sense, the pathogen inactivation kinetics followed the 
Weibull distribution. Angelidis et al. (2010) observed similar behavior and L. monocytogenes populations decreased throughout the storage period followed the Weibull distribution.

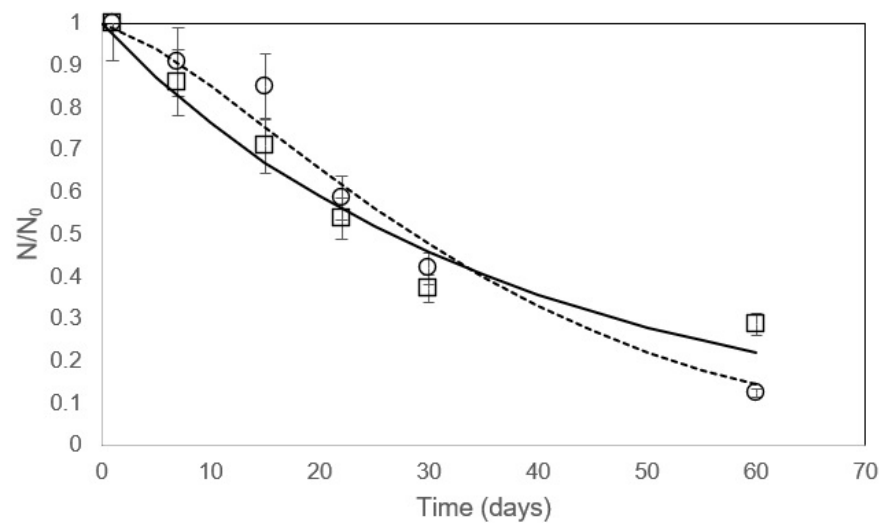

Figure 1. Inactivation of fecal coliforms $(\square)$ and coagulase-positive strain of $S$. aureus $(\circ)$ in serrano artisanal cheese during ripening. Experimental data were fitted to the Weibull model: continuous line represents the tendency curve for coagulase-positive strain of $S$. aureus and dotted line, fecal coliforms.

The LAB are part of the milk microbiota and may play a key role in the cheese ripening, mainly for raw milk. Their biodiversity is closely related to milk production conditions, region, climate, cattle feeding (Arenas et al., 2015; Leclercq-Perlat et al., 2015). Specific studies on serrano artisanal cheese are scarce in the literature. Souza et al. (2003) observed that LAB consisted of the main group of microorganisms in serrano artisanal cheeses. Authors also verified that the high concentration of bacteria from genus Lactobacillus played an important role for food safety. Microorganism biodiversity in raw milk cheeses presents potential to be used for improving food quality (Carafa et al., 2016). Bellio et al. (2016) observed that artificial inoculation methods of L.monocytogenes and $S$. aureus populations were reduced during cheese maturation from raw milk. Shrestha et al. (2011) reported that LAB compete with L. monocytogenes in cheeses during ripening, being able to inhibit foodborne pathogens. Callon et al. (2016) verified that the biodiversity of the LAB for cheese made from raw milk showed 41 strains of this LAB, highlighting the development of an antagonistic activity against $E$. coli $\mathrm{O} 26: \mathrm{H} 11$ and O157: $\mathrm{H} 7$.

The Weibull model considers that the combination of $b$ - and $n$-values could result in the observed inactivation behavior. In this sense, the reliable life $\left(t_{\mathrm{R}}\right)$ concept, meaning the $90 \%$ percentile of the failure time distribution, which is analogous to the $D$-value employed in first-order analysis (van Boekel, 2002) is calculated by Equation 8:

$t_{R}=[(2.303) / b]^{1 / n}$

The $t_{R}$ for inactivation of fecal coliforms was estimated to be 68 days and for coagulase-positive strain of S. aureus, 92 days. Reliable life for reduction of L. monocytogenes Scott A in raw milk cheese at $12{ }^{\circ} \mathrm{C}$ is estimated to be 75 days, and for strain CA, 55 days, according to data published by Angelidis et al. (2010). In raw sheep milk cured cheese, a pool of three different strains of L.monocytogenes presented $t_{R}$ of 60 days during ripening at $12{ }^{\circ} \mathrm{C}$ (Valero et al., 2014).

According to the Brazilian Regulatory Standards (Brasil, 2001), it is noted that semi-hard cheeses, such as serrano cheeses, fecal coliforms and coagulase-positive strain of $S$. aureus population cannot exceed $3 \log$ $\mathrm{CFU} / \mathrm{g}$ for commercialization. $S$. aureus is an enterotoxin producer bacterium, which toxin is thermostable and resistant to several proteolytic enzymes (Jay, 2005). Current Brazilian Regulation (Brasil, 2019) indicated absence of staphylococcal enterotoxin in cheeses for commercialization, due to these characteristics. Figure 2 indicated that initial $S$. aureus concentration was about $7 \log \mathrm{CFC} / \mathrm{g}$, and literature indicated that population above $5 \mathrm{log}$ UFC/g may produce toxin in foods (Cardoso et al., 1985). This 
concentration in the serrano artisanal cheeses could be reached after 18 days of ripening (Figure 2), then, additional caution may be taken for the presence of enterotoxins in the products.

The absence of Salmonella spp. and L.monocytogenes is mandatory (Brasil, 2001), fortunately not being found in the products analyzed, and in agreement to the Brazilian regulation. For adequacy to the other microbiological parameters, serrano artisanal cheeses must be ripened for at least 33 days for both fecal coliforms and coagulase-positive strain of $S$. aureus, according to Equations 5 and 6 and, and which can be seen in Figure 2, where experimental data are plotted. These results agree to Souza et al. (2003), who concluded that serrano artisanal cheeses ripening should be longer than 30 days to allow microbiological stabilization. Additionally, Cruz \& Menasche (2014) observed that serrano artisanal cheeses took an average of 25-30 days to ripe, and if the dairy product is consumed with shorter period of storage it presents milk whey flavor.
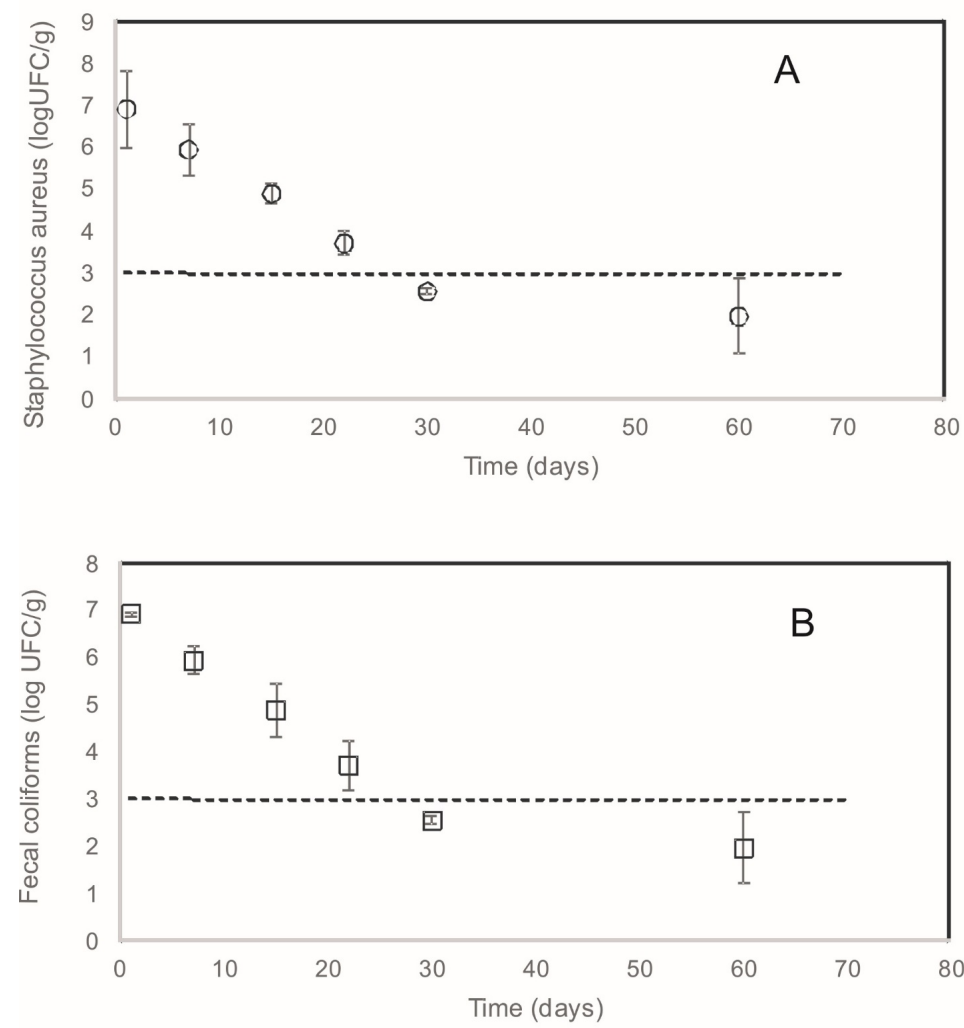

Figure 2. Experimental data of reduction of coagulase-positive strain of S. aureus (A) and fecal coliforms (B) in serrano artisanal cheese during ripening. Dotted lines represent limit population for food safety according to Brazilian regulations.

It is important to point out that postprocessing contamination of the product should be austerely avoided as the pathogen can survive in the product for extended periods of time (Angelidis et al., 2010). Pinto et al. (2009) could relate that one kind of raw-milk Brazilian artisanal cheese was not in agreement to the Brazilian policy because there was a lack of GMP. These observations were reinforced by Yoon et al. (2016), who highlighted the importance of controlling the production quality of raw milk cheese according to the GMP, being ripening a tool to control pathogen and spoilage microorganisms. Additionally to GMP, practices such as regular checks of animal health, testing of milk and the processing establishment to meet hygiene requirements are essential to ensure product safety (Dixon, 2000 apud Brooks et al., 2012). 


\section{Conclusion}

The use of Weibull equation to describe the reduction of $S$. aureus and fecal coliforms populations in serrano artisanal cheeses could be characterized as a comprehensive alternative when compared to other models described in the literature. The products did not present positive results for the presence of Salmonella spp. and L. monogyatogenes. Kinetics showed an initial resistance of fecal coliforms to be inactivated, unlike to $S$. aureus population. Modeling analysis allowed estimating the ripening period of serrano artisanal cheese to be longer than 33 days for achieving a safe product according to the Brazilian Regulatory Standards. Additional research in view of investigating the presence of staphylococcal enterotoxin in serrano artisanal cheese may be performed in order to ensure the food safety. More studies may be conducted with the view to precisely estimate the minimum maturation period of raw milk cheeses.

\section{Acknowledgements}

This project has received funding from the State University of Rio Grande do Sul (Universidade Estadual do Rio Grande do Sul (UERGS), Porto Alegre, Brazil) and from Verità Veterinary Research and Diagnostic Institute (Santa Catarina, Brazil) regarding technical support in microbiological analyzes. Authors declare that they have no conflict of interest.

\section{References}

Angelidis, A. S., Boutsiouki, P., \& Papageorgiou, D. K. (2010). Loss of viability of Listeria monocytogenes in contaminated processed cheese during storage at 4,12 and $22^{\circ} \mathrm{C}$. Food Microbiology, 27(6), 809-818. PMid:20630324. http://dx.doi.org/10.1016/j.fm.2010.04.017

Arenas, R., González, L., Sacristán, N., Tornadijo, M. E., \& Fresno, J. M. (2015). Compositional and biochemical changes in Genestoso cheese, a Spanish raw cow's milk variety, during ripening. Journal of the Science of Food and Agriculture, 95(4), 851-859. PMid:25410683. http://dx.doi.org/10.1002/jsfa.7011

Bellio, A., Astegiano, S., Traversa, A., Bianchi, D. M., Gallina, S., Vitale, N., Zuccon, F., \& Decastelli, L. (2016). Behavior of Listeria monocytogenes and Staphylococcus aureus in sliced, vacuum-packaged raw milk cheese stored at two different temperatures and time periods. International Dairy Journal, 57, 15-19. http://dx.doi.org/10.1016/j.idairyj.2016.02.003

Benlloch-Tinoco, M., Pina-Pérez, M., Martínez-Navarrete, N., \& Rodrigo, D. (2014). Listeria monocytogenes inactivation kinetics under microwave and conventional thermal processing in a kiwifruit puree. Innovative Food Science Emmerging Technology, 22, 131-136. http://dx.doi.org/10.1016/j.ifset.2014.01.005

Brasil. Ministério da Saúde. Agência Nacional de Vigilância Sanitária - ANVISA. (2001, janeiro 10). Regulamento técnico sobre padrões microbiológicos para alimentos (Resolução RDC n 12, de 2 de janeiro de 2001). Diário Oficial [da] República Federativa do Brasil, Brasília, seção 1. Retrieved in 2018, November 28, from http://portal.anvisa.gov.br/documents/33880/2568070/RDC_12_2001.pdf/15ffddf6-3767-4527-bfac-740a0400829b

Brasil. Ministério da Agricultura, Pecuária e Abastecimento - MAPA. (2003, agosto 26). Oficializar os Métodos Analíticos Oficiais para Análises Microbiológicas para Controle de Produtos de Origem Animal e Água (Instrução Normativa n62, de 26 de agosto de 2003). Diário Oficial [da] República Federativa do Brasil, Brasília, seção 1. Retrieved in 2021, March 20, from https://pesquisa.in.gov.br/imprensa/jsp/visualiza/index.jsp?jornal=1\&pagina=1\&data=03/10/2003.

Brasil. (2017, março 29). Regulamenta a Lei $n^{\circ} 1.283$, de 18 de dezembro de 1950, e a Lei $n^{\circ} 7.889$, de 23 de novembro de 1989, que dispõem sobre a inspeção industrial e sanitária de produtos de origem animal (Decreto $n^{\circ} 9.013$ de 29 de março de 2017). Diário Oficial [da] República Federativa do Brasil, Brasília. Retrieved in 2018, November 28, from http://www.planalto.gov.br/ccivil_03/_Ato2015-2018/2017/Decreto/D9013.htm

Brasil. Ministério da Saúde. Agência Nacional de Vigilância Sanitária - ANVISA. (2019, dezembro 26). Estabelece as listas de padrões microbiológicos para alimentos (Instrução Normativa n 60, de 23 de dezembro de 2019). Diário Oficial [da] República Federativa do Brasil, Brasília, seção 1. Retrieved in 2018, November 28, from http://www.in.gov.br/en/web/dou/-/instrucaonormativa-n-60-de-23-de-dezembro-de-2019-235332356

Brooks, J. C., Martinez, B., Stratton, J., Bianchini, A., Krokstrom, R., \& Hutkins, R. (2012). Survey of raw milk cheeses for microbiological quality and prevalence of foodborne pathogens. Food Microbiology, 31(2), 154-158. PMid:22608218. http://dx.doi.org/10.1016/j.fm.2012.03.013

Callon, C., Arliguie, C., \& Montel, M. C. (2016). Control of Shigatoxin-producing Escherichia coli in cheese by dairy bacterial strains. Food Microbiology, 53(Pt B), 63-70. PMid:26678131. http://dx.doi.org/10.1016/j.fm.2015.08.009

Carafa, I., Clementi, F., Tuohy, K., \& Franciosi, E. (2016). Microbial evolution of traditional mountain cheese and characterization of early fermentation cocci for selection of autochtonous dairy starter strains. Food Microbiology, 53(Pt B), 94103. PMid:26678135. http://dx.doi.org/10.1016/j.fm.2015.09.001 
Cardoso, V. M., Silva, G. G., \& Cano, V. (1985). Contagem de microorganismos. In N. Silva (Ed.), Análise microbiológica de alimentos (pp. 20-27). Rio de Janeiro: Quimitra.

Carmo, L. S., Dias, R. S., Linardi, V. R., Sena, M. J., Santos, D. A., Faria, M. E., Pena, E. C., Jett, M., \& Heneine, L. G. (2002). Food poisoning due to enterotoxigenic strains of Staphylococcus present in Minas cheese and raw milk in Brazil. Food Microbiology, 19(1), 9-14. http://dx.doi.org/10.1006/fmic.2001.0444

Corradini, M. G., \& Peleg, M. (2004). A model of non-isothermal degradation of nutirients, pigments and enzymes. Journal of the Science of Food and Agriculture, 84(3), 217-226. http://dx.doi.org/10.1002/jsfa.1647

Cremonesi, P., Perez, G., Pisoni, G., Moroni, P., Morandi, S., Luzzana, M., Brasca, M., \& Castiglioni, B. (2007). Detection of enterotoxigenic Staphylococcus aureus isolates in raw milk cheese. Letters in Applied Microbiology, 45(6), 586-591. PMid:17916131. http://dx.doi.org/10.1111/j.1472-765X.2007.02231.x

Cruz, F. T., \& Menasche, R. (2014). Tradition and diversity jeopardised by food safety regulations? The Serrano Cheese case, Campos de Cima da Serra region, Brazil. Food Policy, 45, 116-124. http://dx.doi.org/10.1016/j.foodpol.2013.04.014

Cruz, F. T., \& Schneider, S. (2010). Qualidade dos alimentos, escalas de produção e valorização de produtos tradicionais. Revista Brasileira de Agroecologia, 5(2), 22-38. Retrieved in 2018, November 28, from https://orgprints.org/24508/1/Cruz_Qualidade.pdf

Fava, L. W., Hernandes, J. F. M., Pinto, A. T., \& Schimidt, A. (2012). Características de queijos artesanais tipo colonial comercializados em uma feira agropecuária. Acta Scietiae Veterinarea, 40, 1-6. Retrieved in 2018, November 28, from http://www.ufrgs.br/actavet/40-4/PUB\%201084.pdf

Gayán, E., Serrano, M. J., Álvarez, I., \& Condón, S. (2016). Modeling optimal process conditions for UV-heat inactivation of foodborne pathogens in liquid foods. Food Microbiology, 60, 13-20. PMid:27554141. http://dx.doi.org/10.1016/j.fm.2016.06.011

Geeraerd, A. H., Herremans, C. H., \& Van Impe, J. F. (2000). Structural model requirements to describe microbial inactivation during a mild heat treatment. International Journal of Food Microbiology, 59(3), 185-209. PMid:11020040. http://dx.doi.org/10.1016/S0168-1605(00)00362-7

Grosulescu, C., Juneja, V. K., \& Ravishankar, S. (2011). Effects and interaction of sodium lactate, sodium diacetate, and pediocin on thermal inactivation of starved Listeria monocytogenes on bologna. Food Microbiology, 28(3), 440-446. PMid:21356449. http://dx.doi.org/10.1016/j.fm.2010.10.013

Haeghebaert, S., Sulem, P., Deroudille, L., Vanneroy-Adenot, E., Bagnis, O., Bouvet, P., Grimont, F., Brisabois, A., Hervy, C., Espié, E., \& Valk, H. (2003). Two outbreaks of Salmonella enteritidis phage type 8 linked to the consumption of Cantal cheese made with raw milk, France, 2001. Eurosurveillance, 8(7), 151-156. PMid:12941980. http://dx.doi.org/10.2807/esm.08.07.00419en

Jay, J. M. (2005). Microbiologia de alimentos (6. ed., 711 p.). Porto Alegre: Artmed.

Leclercq-Perlat, M. N., Sicard, M., Perrot, N., Trelea, I. C., Picque, D., \& Corrieu, G. (2015). Temperature and relative humidity influence the ripening descriptors of Camembert-type cheeses throughout ripening. Journal of Dairy Science, 98(2), 1325-1335. PMid:25497800. http://dx.doi.org/10.3168/jds.2014-8916

Pinto, M. S., Ferreira, C. L. F., Martins, M. M., Teodoro, V. A. M., Pires, A. C. S., Fontes, L. B. A., \& Vargas, P. I. R. (2009). Segurança alimentar do queijo minas artesanal do serro, minas gerais, em função da adoção de boas práticas de fabricação. Pesquisa Agropecuária Tropical, 10, 342-347. Retrieved in 2018, November 28, from https://www.revistas.ufg.br/pat/article/view/4509

Pretto, A. N., \& Sant'Anna, V. (2017). Serrano cheese: A cultural, quality and legal view. Vigilância Sanitária em Debate: Sociedade, Ciência e Tecnologia, 5(4), 81-87. http://dx.doi.org/10.22239/2317-269x.00886

Ombarak, R. A., Hinenoya, A., Awasthi, S. P., Iguchi, A., Shima, A., Elbagory, A. R. M., \& Yamasaki, S. (2016). Prevalence and pathogenic potential of Escherichia coli isolates from raw milk and raw milk cheese in Egypt. International Journal of Food Microbiology, 221, 69-76. PMid:26824810. http://dx.doi.org/10.1016/j.ijfoodmicro.2016.01.009

Shrestha, S., Grieder, J. A., McMahon, D. J., \& Nummer, B. A. (2011). Survival of Listeria monocytogenes introduced as a postaging contaminant during storage of low-salt Cheddar cheese at 4,10 , and $21^{\circ} \mathrm{C}$. Journal of Dairy Science, 94(9), 4329-4335. PMid:21854905. http://dx.doi.org/10.3168/jds.2011-4219

Sant'Anna, V., Utpott, M., Cladera-Olivera, F., \& Brandelli, A. (2010). Kinetic modeling of the thermal inactivation of bacteriocinlike inhibitory substance P34. Journal of Agricultural and Food Chemistry, 58(5), 3147-3152. PMid:20131794. http://dx.doi.org/10.1021/jf903626w

Schokker, E. P., \& van Boekel, M. A. J. S. (1997). Kinetic modeling of enzyme inactivation: Kinetics of heat inactivation at 90$110^{\circ} \mathrm{C}$ of extracellular proteinase from Pseudomonasfluorescens $22 \mathrm{~F}$. Journal of Agricultural and Food Chemistry, 45(12), 4740-4747. http://dx.doi.org/10.1021/jf970429i

Souza, C. F. V., Dalla Rosa, T., \& Ayub, M. A. Z. (2003). Changes in the microbiological and physicochemical characteristics of serrano cheese during manufacture and ripening. Brazilian Journal of Microbiology, 34(3), 260-266. http://dx.doi.org/10.1590/S1517-83822003000300016

Valero, A., Hernandez, M., De Cesare, A., Manfreda, G., González-García, P., \& Rodríguez-Lázaro, D. (2014). Survival kinetics of Listeria monocytogenes on raw sheep milk cured cheese under different storage temperatures. International Journal of Food Microbiology, 184, 39-44. PMid:24630556. http://dx.doi.org/10.1016/j.ijfoodmicro.2014.02.017

van Boekel, M. A. J. S. (2002). On the use of the Weibull model to describe thermal inactivation of microbial vegetative cells. International Journal of Food Microbiology, 74(1-2), 139-159. PMid:11930951. http://dx.doi.org/10.1016/S0168-1605(01)007425 
Yoon, Y., Lee, S., \& Choi, K. H. (2016). Microbial benefits and risks of raw milk cheese. Food Control, 63, 201-215. http://dx.doi.org/10.1016/j.foodcont.2015.11.013

Funding: This project has received financial support from the State University of Rio Grande do Sul (Universidade Estadual do Rio Grande do Sul) (UERGS), Porto Alegre, Brazil and from Verità Veterinary Research and Diagnostic Institute

(Santa Catarina, Brazil) regarding technical of support in microbiological analyzes. 